\title{
Impact of Fertilizer Usage on Crop Productivity at Siguidolo
}

\author{
Djeneba Dembele ${ }^{1 *}$, Mamadou Ballo², Abdou Ballo ${ }^{3}$, Bocar dit Sire Ba ${ }^{4}$
}

\author{
${ }^{1}$ Laboratoire sol-Eau-Plante, Institut d'Economie Rurale (IER), Mali, \\ ${ }^{2}$ Laboratoire d'Ecologie tropicale, Université des Sciences Techniqueset des Technologies de Bamako, Mali \\ ${ }^{3}$ Département de Géographie, University des Sciences Sociales de Bamako, Mali \\ ${ }^{4}$ Danish cooperation, Mali \\ *Corresponding Author: Dr. Djeneba Dembele, djenebademb@yahoo.fr
}

\begin{abstract}
On a poor soil, fertilizers application is the best ways to meet crop need and restore the lost nutrients. However, its application is constrained in Mali due to the low access to fertilizers by smallholder farmers, resulting in low crop production. Today, make available to farmer's fertilizer and information needed for its proper use is an essential asset for sustainable agriculture and food security. Before, assessing the existing fertilizer usage and it impact on yield is a prerequisite. A study was done to characterise fertiliser management practices at Siguidolo and assess the impact on millet and sorghum yields. Thus, normalized difference vegetation Index (NDVI) and visual interpretation were used to estimate vegetation cover as sources of organic matter (OM). Investigation was doneto get information about manure production and areas occupied by crop production. Geographic Information System and Survey was done to obtain information on fields, fertilizer used and yields. The results showed low vegetation cover (0.02 to 0.24) indicating low source of organic matter. The mean manure produced was $14373 \mathrm{~kg} / \mathrm{ha} /$ year while $69300 \mathrm{~kg}$ was recommended. Organic fertilizers and integrated organic and mineral fertilizers occupied greater area. About $24.1 \%$ of the area did not received fertilizer. The extremely low fertility areas tended to receive more nutrient application. Indications are that, even in those areas where fertilizers were applied, the right quantities were seldom used. Low yield for millet and sorghum was recorded ranging from $414.66 \mathrm{~kg} \mathrm{ha}^{-1}$ to $703.80 \mathrm{~kg} \mathrm{ha}^{-1}$ for millet and $404.12 \mathrm{~kg} \mathrm{ha}^{-1}$ to $448.04 \mathrm{~kg} \mathrm{ha}^{-1}$ for sorghum.
\end{abstract}

Keyword-Fertilizer, usage, crop, productivity, Siguidolo.

\section{INTRODUCTION}

One of the main factors limiting crop efficiency and food security in Mali is the low natural fertility of the soils and its continued decline over years of cultivation. The decline in soil fertility and low nutrient application is the leading cause of the declining per capita food production in SubSahara Africa (Chianu, 2012; Bremanet al., 1983; Kihara et al., 2016;IFDC, 2006; Shapouri et al., 2010;Muller et al., 2012). Food production index per capita showed a declining trend over the last decades and about $29 \%$ of the population is estimated to be undernourished (FAO stat, 2008). To reverse this trend, it is important to replenish the removed nutrients which results from crop uptake, harvest, erosion and leaching. Fertilizers application is one of the best ways to meet crop need and restore the lost nutrients(Gatti et al. 2019). Fertilizersare any material of natural or synthetic origin which, when applied to soils, provide one or more nutrients essential to plants growth and yield (Barker,2019). They occupy a prominent position in food security challenges on poor soils (Stewarta et al., 2012). However, their application is severely constrained in Mali due to the low access to fertilizer (IFDC, 2015) by the poor smallholder farmers, resulting in low agriculture production. Today in Mali, make available to farmer's fertilizer and information needed for its proper use is an essential asset for promoting sustainable agriculture production and food security while preserving environment. Before, assessing the existing fertilizers usage and it impact on crop production and food security is a prerequisite in the identification and development of appropriate improved practice. The objective of this study was to characterise the existing fertilisers management practices at Siguidolo and assess their impact one millet and sorghum yield in order to develop an improved method.

\section{MATERIALS AND METHODS}

\subsection{Study site}

Siguidolo is located in Segou region of Mali in a depression surrounded by the plateaux. It is between $6.80399^{\circ}$ and $-6.78583^{\circ} \mathrm{N}$ and $12.91624^{\circ}$ and $12.91229^{\circ} \mathrm{W}$. The mean annual rainfall is $700 \mathrm{~mm}$. Soils are mostly 
sandy loam. During the rainy season, interrill (sheet) erosion is common with intermittent rills and gullies, some of which measure up to $1.0 \mathrm{~m}$ deep in the relatively hilly sites. In the depressions and valleys, particularly along the streams, waterlogged conditions often prevail during the rainy season presumably due to high water table.

\subsection{Vegetation cover mapping}

Normalized Difference Vegetation Index (NDVI) calculation and visual interpretation were used on a Quick bird image covering the study site at about $75 \%$. NDVI is the dimensionless index that is indicative of vegetation density and is calculated by comparing the visible and near-infrared sunlight reflected by the plant surface (reflectance). The vegetation Index was used to quantify the density of green leaf vegetation by the formula:

NDVI $=\frac{(N I R-R)}{(N I R+R)}$

Where

$\mathrm{NI}=$ Near Infra;

$\mathrm{R}=$ Red band

When NDVI calculation is applied on an image or a pixel, the output gives a value ranging between minus one $(-1)$ to plus one $(+1)$. A zero value means no green vegetation and close to $+1(0.8-0.9)$ indicates the highest potential density of green leaves. The spatial distribution and the density of vegetation have significant implications on fertilizer practices in an area.

The map derived from NDVI calculation was used for ground verification. Visits were done on various locations of the study area to identify and characterise known and unknown features marked on the map.

\subsection{Assessment of organic manure production capacity}

Investigation was donebeside the households to get information about manure production capacity and the area occupied by agriculture. Dembele (1994) showed that, the average organic manure production by livestock was 153.5 $\mathrm{kg} / \mathrm{head} / 4$ months in rainy season and $182 \mathrm{~kg} / \mathrm{head} / 4$ months in dry season. These data and the number of livestock were used to calculate the average organic manure production during both seasons at Siguidolo. Data were then used to estimate the availability of organic manure per year.

\section{$2.4 \quad$ Fertilizer practices mapping}

Global Positioning System (GPS) was used to delimit farmers' fields. Survey was done to obtain information on the fertilizer practices used in each field. Then, GPS and survey data were combined in Geographic Information System (GIS) environment to map fertilizer practices.

\subsection{Assessment of the impact of fertilizer practices on yield}

Survey was conducted beside the households to found out information about the ways of fertilizer usage (spread or micro-dosing, etc.), the types and amounts of fertilizers used, and yields obtained on the sorghum (Sorghum bicolor L. Moench) and millet (Pennisetumglaucum) fields. 36 out 38 households were interviewed.

\section{RESULTS}

\subsection{Vegetation cover mapping}

Vegetation assessment resulting from NDVI processing is presented in Fig.1.The image used for NDVI calculation covered $75.5 \%$ of the study area. The vegetation index values ranged from -0.01 to 0.24 . This vegetation was classified into three savannah vegetation comprising bare soil $(-0.01-0.02)$, grassland with scattered trees $(0.02$ $0.05)$, and woodland with grass cover $(0.05-0.24)$. The bare soil covered 278.26 ha $(31.69 \%)$ of the area. The grassland with scattered trees occupied 451.01 ha $(51.36 \%)$ and comprised grasses, such as Andropogonguayanus, crop residues and shrubs, such as Piliostigmareticulatum. The woodland had an aerial extent of 148.93 ha $(16.62 \%)$ and consisted of green vegetation including Vitellariaparadoxa, Parkiabiglobosa, Adansoniadigitata,

Lanneamicrocarpa and Lanneaacida
Piliostigmareticulatum on the bottom of the toposequence, then some Lanneamicrocarpa and acida, Zizziphusmauritiana, Guierasenegalensis, Combretummicranthum, Combretonglutinosiun, Bauhinia rufescens, Bauhinia reticulate, Pennisetumpedicelatum, on the top of the toposequence. 


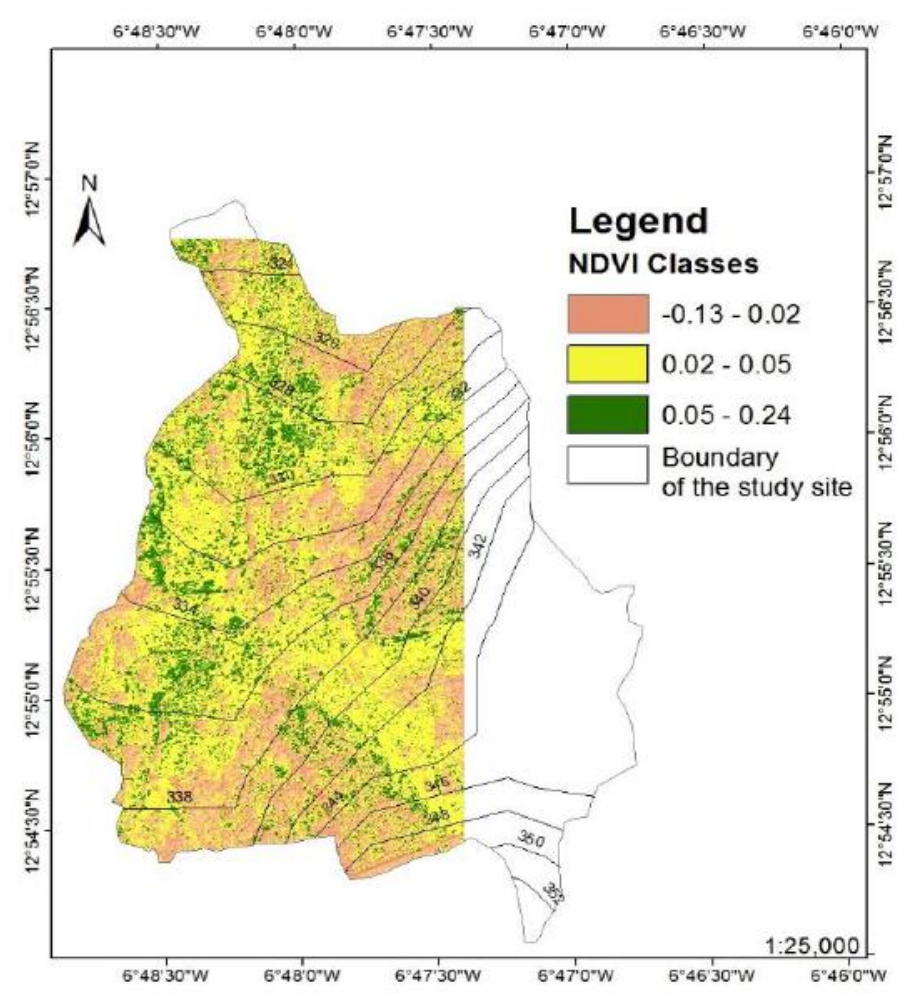

Fig.1: NDVI of the study area from Quick bird image in 2014

\subsection{Assessment of organic manure availability}

A total of 398 cattle, 274 sheep, 312 goats and 43 donkeys were identified in the village. Table 1 shows the results of the basic statistical analysis about livestock. The mean values give the general magnitude of the data and the $\mathrm{CV}$ show the high variability between the household concerning livestock possession (minimum 0 and maximum 42). The mean bovine per household was higher than the others animals. Some households don't possess animal.

Table.1: Livestock available at Siguidolo in 2014

\begin{tabular}{|c|c|c|c|c|}
\hline livestock & Bovine & Ovine & Goat & Donkey \\
\hline Mean & 11.06 & 7.61 & 8.7 & 1.19 \\
\hline Median & 5.00 & 3.50 & 5 & 1 \\
\hline Minimum & 0 & 0 & 0 & 0 \\
\hline Maximum & 41 & 42 & 40 & 10 \\
\hline $\begin{array}{l}\text { Coefficient of } \\
\text { variation }(\mathrm{CV})\end{array}$ & 102.56 & 131.32 & 116.73 & 158.62 \\
\hline
\end{tabular}

Organic manure production capacity is presented in Table2. Organic manure production was high in dry season. The highest amount of organic manure was produced by bovine.

Table.2: Organic manure production capacity at Siguidolo in 2014

\begin{tabular}{|c|c|c|c|c|c|}
\hline $\begin{array}{l}\text { Average production of } \\
\text { organic manure }(\mathrm{kg})\end{array}$ & Bovine & Ovine & Goat & Donkey & Total \\
\hline $\begin{array}{l}\text { Rainy Season } \\
\text { (4 mouths) }\end{array}$ & 1698 & 1168 & 1335 & 183 & 4384 \\
\hline $\begin{array}{l}\text { Dry Season' } \\
\text { (4months) }\end{array}$ & 2013 & 1385 & 1583 & 217 & 5198 \\
\hline
\end{tabular}




\begin{tabular}{llllll}
\hline Year & 5566 & 3830 & 4378 & 599 & 14373
\end{tabular}

The type of mineral fertilizer used in the study site in 2014 is presented in Table3. The Complexes Cereal is the most used with the mean of $102.1 \mathrm{~kg} / \mathrm{ha}$. NPK was not used at the site in 2014 .

Table.3: Mineral Fertilizers used at Siguidolo in 2014.

\begin{tabular}{lllll}
\hline $\begin{array}{l}\text { Mineral fertilizer } \\
(\mathbf{k g} / \mathbf{h a})\end{array}$ & $\begin{array}{l}\text { Complexes } \\
\text { Cereal }\end{array}$ & DAP & NPK & Urea \\
\hline Mean & 102.1 & 4.29 & 0 & 38.21 \\
Median & 50 & 0 & 0 & 0 \\
Minimum & 0 & 0 & 0 & 0 \\
Maximum & 500 & 50 & 0 & 150 \\
CV & 118.5 & 331.37 & 0 & 123.66 \\
\hline
\end{tabular}

\subsection{Fertilizer practices mapping}

Fertilizer's practices data collected on the site was overlaid on the soil fertility status map (Fig. 2) in order to understand the link between soil fertility status and farmer's fertilizers application decision. The fertility status varied from low, to extremely low. The very low status covered the greater area. Their respective area of coverage was 42.54 ha $(4.81 \%), 134.9$ ha $(15.26 \%)$ and 706.61 ha $(79.93 \%)$.

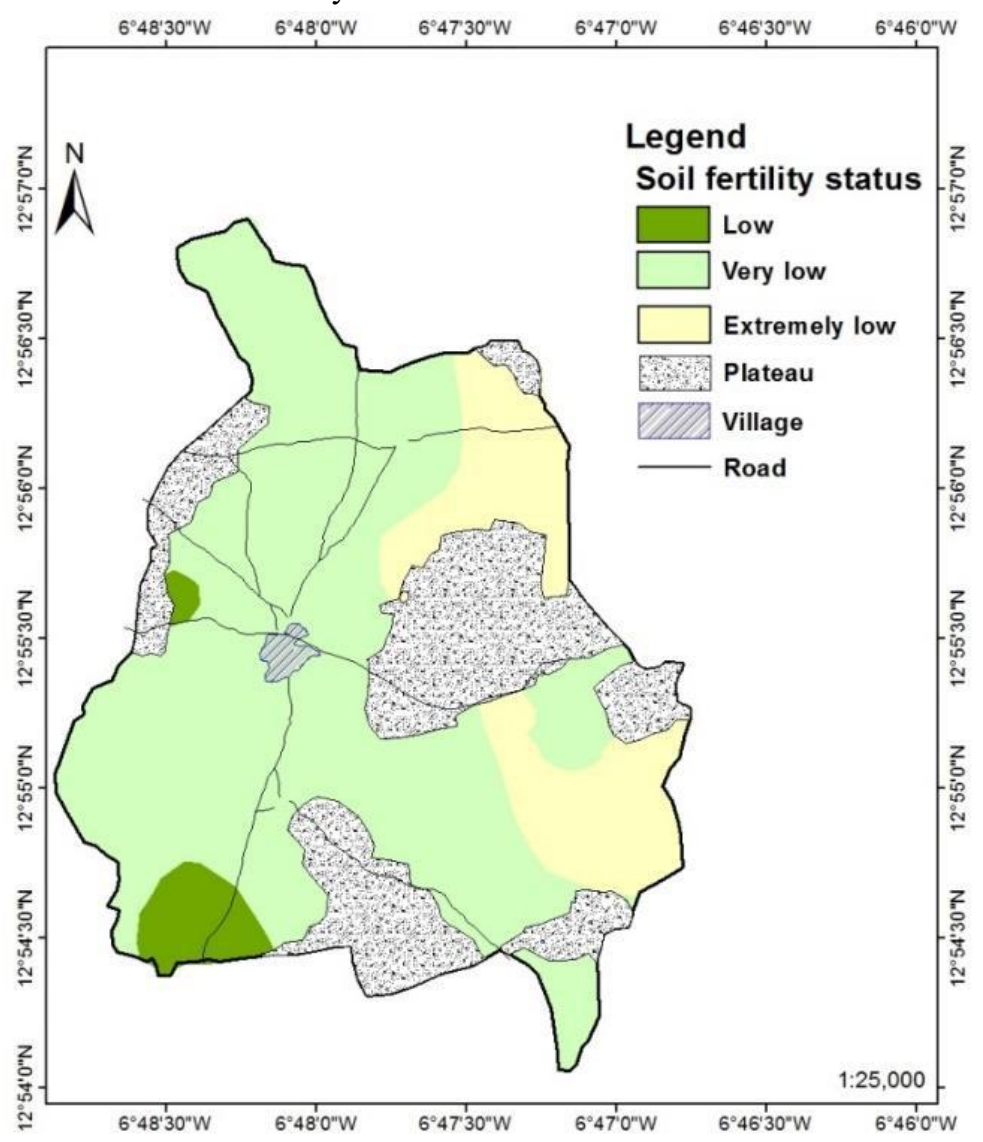

Fig.2: Spatial distribution of soil fertility status at Siguidolo in 2013.

The spatial distribution of the fertilizers used in 2013 is presented in Figure3. Fertilizer used were: complex cereal $(\mathrm{CCl})$, complexecoton $(\mathrm{CCt})$, urea $(\mathrm{U})$, DAP, NPK,
Organic fertilizer (OF). The extremely low fertility area tended to receive more nutrient application. 


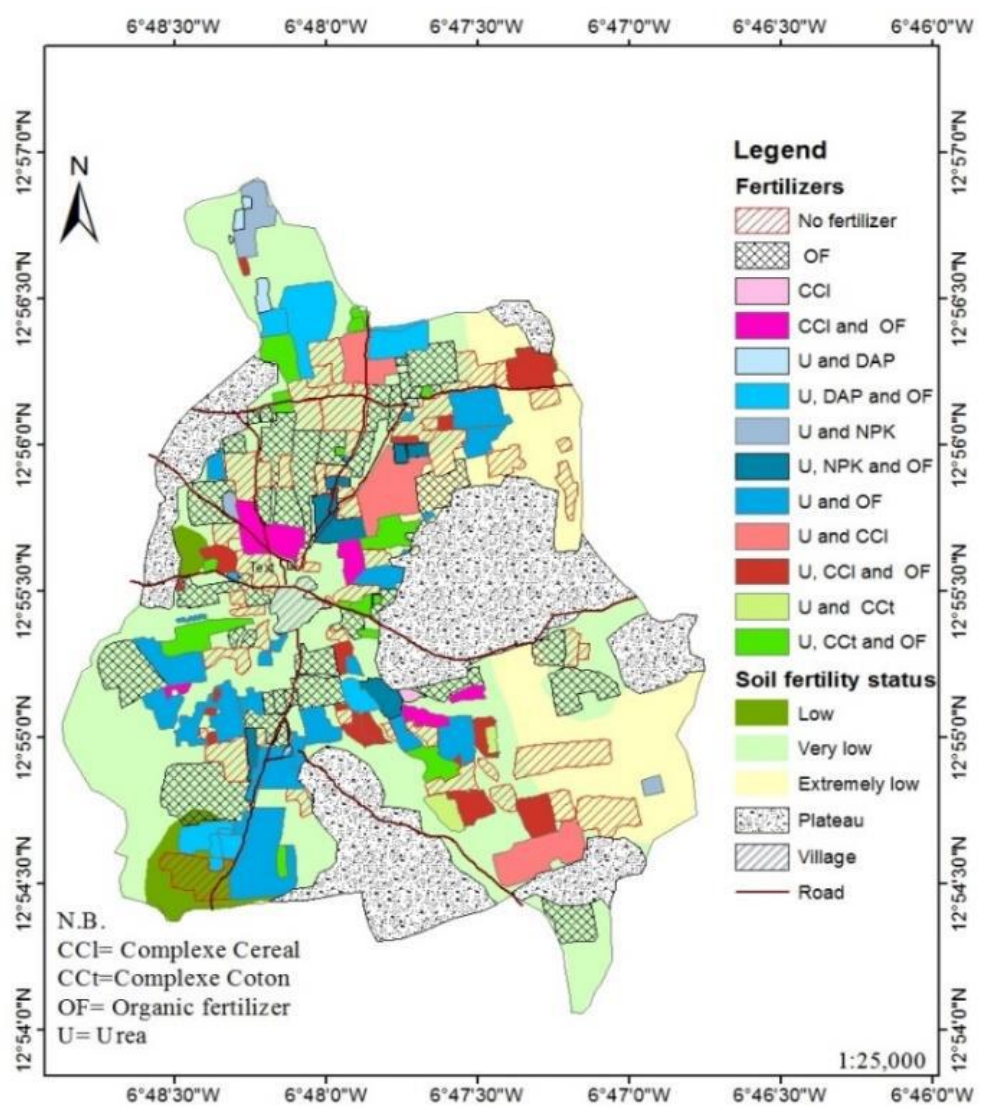

Fig.3: Spatial distribution of fertilizers usage at Siguidolo in 2013

Table4 shows the areal coverage of fertilizers. Organic fertilizers and integrated organic and mineral fertilizers occupied the greatest area of 333.51 ha over 506 ha. About $24.1 \%$ of the area did not received fertilizer.

Table.4: Areas covered by fertilizers in 2013.

\begin{tabular}{lll}
\hline Fertilizers & Area (ha) & Area $(\%)$ \\
\hline No fertilizer & 122 & 24.11 \\
Organic fertilizer & 132.01 & 26.08 \\
Mineral fertilizer & 50.2 & 9.90 \\
Organic and mineral fertilizer & 201.5 & 39.93 \\
\hline Total & 506 & $100 \%$ \\
\hline
\end{tabular}

Table5 shows the soil amendments applied in 2013 and percentage area of coverage. The very low fertility areas tended to receive more nutrient application.

Table.5: Soil amendments applied in 2013 and percentage area of coverage.

\begin{tabular}{|c|c|c|c|}
\hline \multirow[t]{3}{*}{ Soil amendments } & \multicolumn{3}{|c|}{ Soil fertility status } \\
\hline & Low & Very low & Extremely low \\
\hline & \multicolumn{3}{|c|}{ 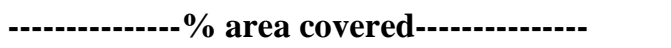 } \\
\hline No fertilizer & 55.57 & 19.67 & 28.96 \\
\hline Organic fertilizer & 15.82 & 23.69 & 40.76 \\
\hline Mineral fertilizer & - & 12.87 & 1.99 \\
\hline Organic and mineral fertilizer & 28.61 & 43.77 & 28.29 \\
\hline Total & 100 & 100 & 100 \\
\hline
\end{tabular}


3.4 Assessment of the impact of fertilizer practices on yield

Information on soil fertility status, spatial distribution of millet and sorghum grain yields is presented in Figures 4 and 5, respectively. The means millet grain yield was $414.66 \mathrm{~kg} \mathrm{ha}^{-1}$ on soil with low nutrient status, $703.80 \mathrm{~kg}$ $\mathrm{ha}^{-1}$ on soil with very low nutrient status and $558.2 \mathrm{~kg} \mathrm{ha}^{-1}$ on soil with extremely low nutrient status. The corresponding yields for sorghum were $445 \mathrm{~kg} \mathrm{ha}^{-1}, 448.04$ $\mathrm{kg} \mathrm{ha}^{-1}$ and $404.12 \mathrm{~kg} \mathrm{ha}^{-1}$ respectively. The very low and extremely low nutrient status soils were compensated by greater amounts of fertilizer application with a consequent higher grain yield than the relatively better low fertility soils. The percentage area of the low, very low and extremely low fertility status soils that received fertilizers were $44.4,80.33$ and 71.01 respectively.

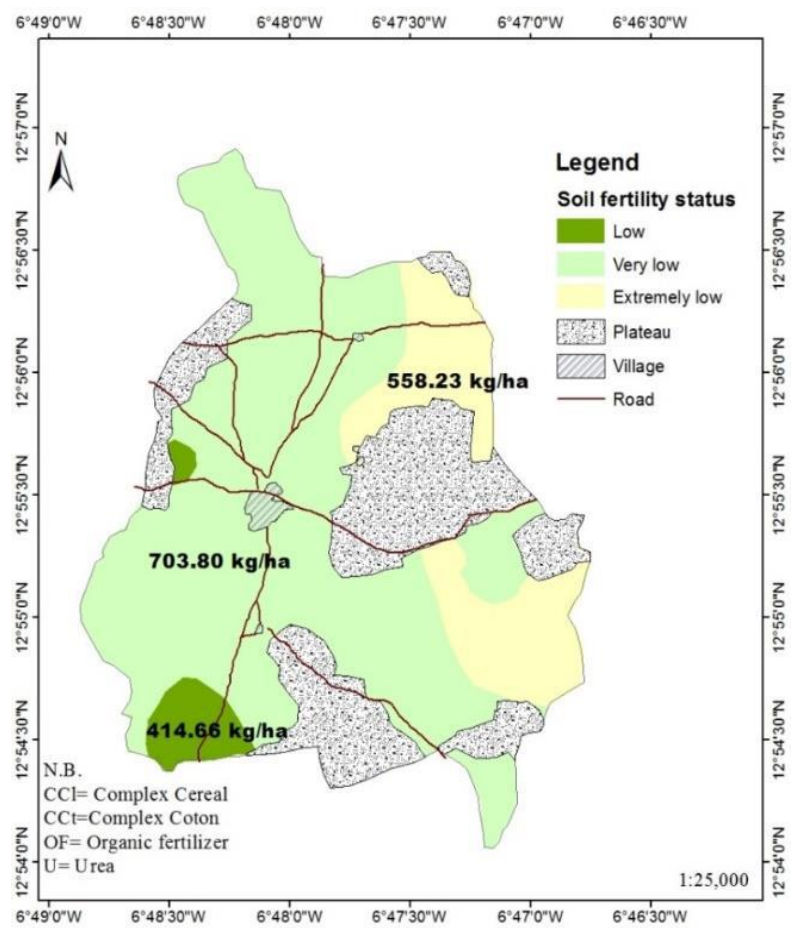

Fig.4: Spatial distribution of soil fertility status and millet grain yield in 2014.

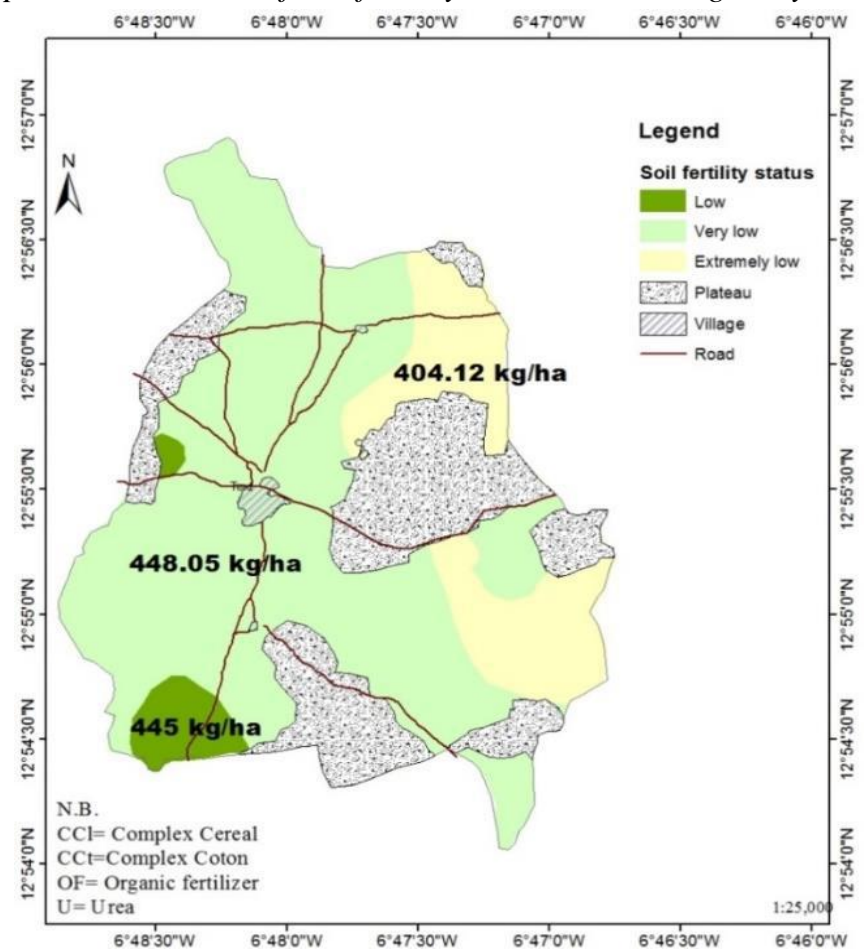

Fig,5: Spatial distribution of soil fertility status and sorghum grain yield in 2014. 


\section{DISCUSSION}

Vegetation is source of organic matter (OM). OM has many beneficial effects soil (Erich et al., 2002; Sanyal et al., 1991). It improves the physical, chemical and biological properties of the soil.Thus, Maurice et al.(1998) used organic matter as an indicator of soil fertility, overall soil stability and a factor influencing the reduction of soil erosion, soil compaction and bulk density (Vorhees, W.B. 1992). Fen-Li (2006) found that the vegetation effect on soil erosion was predominant.As Soil Organic Matter increases, the quantities of $\mathrm{N}, \mathrm{P}, \mathrm{K}$ available, carbon and certain micronutrients increase (Oates, 1998, Dembele, 2017).Acquaye (1990) reported that organic matter was the main source of $\mathrm{N}, \mathrm{P}$ and $\mathrm{S}$ for plant growth in small farms without fertilizer. Nitrogen $(\mathrm{N})$ use in crop production is inevitable target (Rossner et al. 2014).In addition, soil water infiltration is more influenced by vegetal cover and soil organic matter(Sampaiode Almeida, et al., 2018)as well as nutrient and water holding capacities (Lal et al., 1998, Traore, 2003; Morgan, 2005; Barmani et al., 2013). They improvesoil microorganism activities (Havlin et al., 2005),soil aeration,plant root growthand elongation and $\mathrm{pH}$ stability.Furthermore, vegetation covers cushions the soil against the erosive forces of water and wind (VásquezMéndez et al., 2009,) and thereby reduce their detachment and transport capacities with a resultant reduction in erosion.Assessing the vegetation cover of the study site therefore became necessary. The effectiveness of vegetative cover in reducing erosion however depends, in part, on its density and spatial coverage, the continuity of the canopy and height (Nanko et al., 2008). NDVI at Siguidolo varied from -0.01 to 0.24 indicating low and sparse vegetation covert and very low source of organic matter. This condition has negative effects on soil fertility and influences fertilizer management strategies.

Manure production capacity impacts soil fertility in Mali because small scale farmers don't own enough money to afford mineral fertilizer at the recommended level (Jens and al., 2007; PRSP, 2002). A mean of 11.06 cattle's, 7.61 sheep, 8.7 goats and1.19 donkeys per household was investigated in the site which produce $14373 \mathrm{~kg} / \mathrm{year}$ of organic manure. This amount is not sufficient to meet a mean of 13.86 ha/household measured in the area where $5 \mathrm{t} / \mathrm{ha}$ is recommended.ExceptComplexes Cereal, the mean of the other mineral fertilizers used in the site was significantly below the recommended rate of $50 \mathrm{~kg} / \mathrm{ha}$ of DAP and $50 \mathrm{~kg} / \mathrm{ha}$ of Uréanoted byOuendeba (2010). Analysis has shown that the very low fertility area tended to receive more nutrient application. Indications are that, even in those areas where fertilizers were applied, the right quantities were seldom used. Sorghum and millet yields recorded in the study site were significantly low compared to $1424 \mathrm{kgha}^{-1}$ and $1301 \mathrm{~kg} \mathrm{ha}^{-1}$ for millet in 2013 and 2014, respectively and $1378 \mathrm{~kg} \mathrm{ha}^{-1}$ for sorghum in 2014 harvested in research station by Traore et al. (2017).

Increasing Crop production and productivity atSuigidolo area, dominated by smallholder farmers require a set of accompanying soil conservation and efficient water utilization technologies.Sound soil fertility management, as recommended by Quansah (2000), should therefore use available livestock and poultry manure and crop residues wherever practical, taking appropriate nutrient credit for these materials and using mineral fertilizers to balance the crops nutritional requirements for realistic yield goals. These include ridge furrow system, tie-ridging, circular contour bunds, zai, cereal legume rotations and residue management. In contributing to this effort, the cropping systems in the area need to be study to show trends as a basis for recommending asustainable cropping systemable to improve the biophysical and socio-economic conditions of the farmers.

\section{CONCLUSION}

Agriculture development at Siguidolo involves the improvement of organic matter production, andthe adapted agriculture technologies.

\section{REFERENCES}

[1] Aune, J. B., Doumbia, M. and Berthe, A.,2007.Microfertilizing sorghum and pearl millet in Mali, Agronomic, economic and social feasibility, Outlook on Agriculture Vol36, No 3, pp 199-203

[2] Barmani, S., Aggarwali, S.P. and Dutta, M.K.,2013.Soil Erosion Due to Change in Vegetated Area in the Majuli Island of Assam, International Journal of Advancement in Remote Sensing, GIS and Geography. Vol.1, No.1, 8-19.

[3] Barker A. V., 2019.Fertilizers, Elsevier, Encyclopedia of Analytical Science (Third Edition), Pages 134-144, doi.org/10.1016/B978-0-12-409547-2.00142-6

[4] Breman, H., de Wit, C.T. 1983.Rangeland productivity and exploitation in the Sahel,Science, Volume 221, Issue 4618, pp. 1341-1347, DOI: 10.1126/ science. 221.4618.1341

[5] Chianu, J. andChianu, M. J.,2012.Mineral fertilizers in the farming systems of sub-Saharan, A review, Agronomy for Sustainable Development, Springer Verlag/EDP Sciences/INRA, 2012, 32 (2), pp.545-566., 10.1007/s13593-011-0050-0.,HAL-00930525.

[6] DEMBELE D. Quansah C., BA B. S., 2017,Assessment of the impact of profeba on acid soil and the sorghum and millet yields under ridge and hoe tillages in sahelienne zone in Mali, International Journal of agricultural Science and Research (IJASR), ISSN(P):2250-0057; 2321-0087, Vol 7, Issue 1, feb 2017, 247-266.http://www.tjprc.org/view archives.php?year=2017_104_2\&id=50\&jtype $=2 \&$ page $=3$ 
[7] Dembele D., Traore K., Quansah C., Osei EM., BA BS.andBallo M. 2016. Optimizing Soil Fertility Management Decision in Mali by Remote Sensing and GIS Donnish Journal of Agricultural Research Vol3(4) pp. 022034 November, 2016.

[8] Dembele, I. 1994.Production et Utilisation de la fumure organique, Fiche synthétique d'information, Document $\mathbf{N}^{\circ} \mathbf{9 4} / 19$

[9] Erich MS., Fitzgerald CB. and Porter, GA. 2002. The effect of organic amendments on phosphorus chemistry in a potato cropping system, Department of Plant, Soil, and Environmental Sciences, University of Maine, Orono.

[10] FAO 1996.Food security statistics, http://www.fao.org/economic/ess/ess-fs/en/

[11] Fen-Li Z., 2006, Effect of Vegetation Changes on Soil Erosion on the Loess Plateau, Elsevier, Pedosphere, Volume 16, Issue 4, August 2006, Pages 420-427 https://doi.org/10.1016/S1002-0160(06)60071-4

[12] Gattia M., Schippac M., Garavani A., Squeri C., Frioni T., Dosso P., Poni S., 2019. High potential of variable rate fertilization combined with a controlled released nitrogen form at affecting cv. Barbera vines behavior, Elsevier, European Journal of Agronomy 112 (2020) 125949, Volume 112, January 2020,

[13] Havlin J. L., Beaton J. D., Tisdale S. L. and Nelson, W. L.,2005. Soil fertility and fertilizers: An introduction to nutrient management (7 ed.). New Jersey: Pearson prentice hall.

[14] http://internationalmonetaryfund.com/external/pubs/ft/scr/2 003/cr0339.pdf

[15] IFDC, 2006. IFDC Africa Fertilizer Summit Proceedings, Abuja, Nigeria June 9-13 2006, IFDC, Florence, Alabama (2006)

[16] J. Kihara, G. Nziguheba, S. Zingore, A. Coulibaly, A. Esilaba, V. Kabambe, S. Njoroge, C. Palm, J. Huising, 2016. Understanding variability in crop response to fertilizer and amendments in sub-Saharan Africa, Elsevier, Agriculture, Ecosystems and Environment, Volume 229, Pages 1-12, https://doi.org/10.1016/j.agee.2016.05.012

[17] Lal R. 1998. Soil erosion impact on agronomic productivity and environment quality:critical reviews. Plant Sciences 17: 319-464

[18] Morgan, RPC. 2005.Soil Erosion and conservation, $3^{\text {th }}$ Edition, National soil resource institute, Cranfield University.

[19] Muller N.D., Gerber J.S., Johnston M., Ray D.K., Ramankutty N., Foley J.A., 2012. Closing yield gaps through nutrient and water management, Nature, 490:254 257 [Google Scholar]

[20] Ouendeba B. 2011. Fiche de production et de commercialisation du sorgho, Mali = Production and Marketing ofSorghum, Mali, University of Nebraska Lincoln, USAID Mali Mission Awards 3, http://digitalcommons.unl.edu/intsormilusaidmali/3

[21] Poverty Reduction Strategy Paper, 2002. The Government of Mali,
[22] Quansah C., SafoEY.,Ampontuah EO. andAmankwah AS. 2000. Soil fertility erosion and the associated cost NPK removed under different Soil and residue management in Ghana, Ghana Jnl. Agric. Sci. 33:33 - 42.

[23] Rossner H., Ritz C., AstoverA., 2014, Optimisation of fertiliser rates in crop production against energy use indicators, Elsevier, European Journal of Agronomy, Volume 55, April 2014, Pages 7276https://doi.org/10.1016/j.eja.2014.01.003

[24] Sampaiode Almeida W., Panachuki E., Sanchesde Oliveira P. T., Menezes R.S., ,.Sobrinho T. A, Fonsecade Carvalho D., 2018. Effect of soil tillage and vegetal cover on soil water infiltration, Elsevier, Soil and Tillage Research, Volume 175, January 2018, Pages 130-138

[25] Sanyal, S. K. and De Datta, S. K., 1991, Chemistry of phosphorus transformations in soil, Adv. Soil Sci. 16:1-120

[26] Shapouri S., Rosen S., Peters M., Baquedano F., Allen S., 2010. United States Department of Agriculture (USDA). Food Security Assessment, 2010-20: a Report from the Economic Research Service. [Google Scholar]

[27] Stewarta,W.M. and Robertsb,T.L.,2012. Food Security and the Role of Fertilizer in supporting it, 1st International Symposium on Innovation and Technology in the Phosphate Industry [SYMPHOS 2011], Elsevier, Procedia Engineering $\quad 46 \quad(2012) \quad 76$ - 82, doi: 10.1016/j.proeng.2012.09.448

[28] Swift M., 1997. Biological Management of soil fertility: an integrated approach to soil nutrient replenishment, Proceedings of international seminar on Approaches to Replenishing Soil Fertlity in Africa NGO, Perspectives, ICRAF, Nairobi, Kenya.

[29] Traore K. 2003. Le parc a karité : sa contribution à la durabilité de l'agrosystème. Cas d'une toposequence à Konobougou (Mali-Sud). Thèse, Ecole Nationale Supérieure Agronomique de Montpellier.

[30] Traore K., Sidibe DK., Coulibaly H. and Bayala J. 2017.Optimizing yield of improved varieties of millet and sorghum under highly variable rainfall conditions using contour ridges in Cinzana, Mali, Agriculture \& Food Security, DOI 10.1186/s40066-016-0086-0

[31] Vásquez-Méndez R., Ventura-Ramos E., Oleschko K., Hernández-Sandoval L., Parrot JF., Nearing MA., 2009. Soil erosion and runoff in different vegetation patches from semiarid Central Mexico, Elsevier DOI: 10.1016/j.catena.2009.11.003

[32] Vorhees, W. B. 1992. Wheel-induced soil physical limitations to root growth, In and B.O. Stewart eds. Adv. Soil Sci 19:73-92. 